\title{
Hydrochemical Characteristics and Identification of Groundwater Pollution Sources in Tropical Savanna
}

\author{
Abduljalal Abdulsalam ${ }^{1}$, Mohammad Ramli ${ }^{1}$, Nor Jamil ${ }^{1}$, Zulfa Ashaari ${ }^{1}$, and Da'u $\operatorname{Umar}^{2}$ \\ ${ }^{1}$ Universiti Putra Malaysia \\ ${ }^{2}$ Federal University Dutse
}

March 3, 2021

\begin{abstract}
Groundwater pollution of the watershed is mainly influenced by the multifaceted interactions of geogenic and anthropogenic processes. In this study, classic chemical and multivariate statistical methods were used to assess the groundwater quality and identify the potential pollution sources affecting the groundwater quality of Galma sub-watershed in a tropical savannah. For this purpose, the dataset of 18 groundwater quality variables covering 57 different sampling boreholes (BH) was used. The order of abundance of the main cations and anions in the samples are $\mathrm{Ca} 2+>\mathrm{Na}+>\mathrm{Mg} 2+>\mathrm{K}+$ and $\mathrm{HCO} 3->\mathrm{Cl}->\mathrm{SO} 4-2>\mathrm{NO} 3-$ respectively. Piper diagram classified the groundwater types of the watershed into mixed $\mathrm{Ca}-\mathrm{Mg}-\mathrm{Cl}$ type of water, which means no cations and anions exceeds $50 \%$. The second dominant water type was $\mathrm{Ca}-\mathrm{Cl}$. The $\mathrm{Mg}-\mathrm{HCO} 3$ water type was found in $\mathrm{BH} 9$, and $\mathrm{Na}-\mathrm{Cl}$ water type in $\mathrm{BH} 29$ respectively. Hierarchical cluster analysis grouped the sampling boreholes into five statistically significant clusters based on similarities of groundwater quality characteristics. Principal component extracted two principal components that explained around $65 \%$ of the total variance, which natural and anthropogenic processes especially agricultural activities as the dominant factors affecting the groundwater quality. The findings of this study are useful to the policy and decision-makers for formulating efficient groundwater utilization and management plans for the groundwater resources.
\end{abstract}

\section{Hosted file}

Manuscript.pdf available at https://authorea.com/users/399224/articles/511783-hydrochemicalcharacteristics-and-identification-of-groundwater-pollution-sources-in-tropical-savanna 

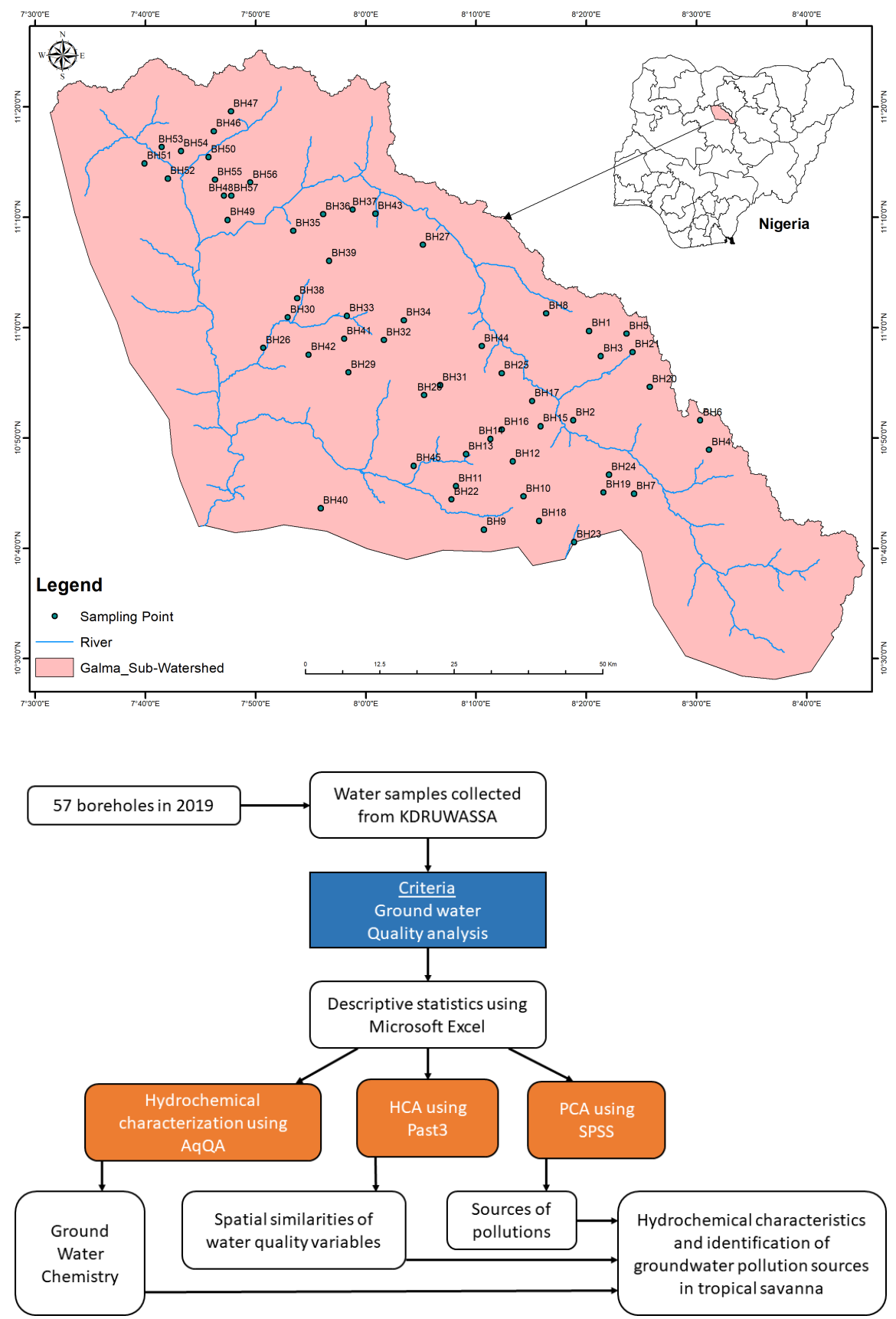

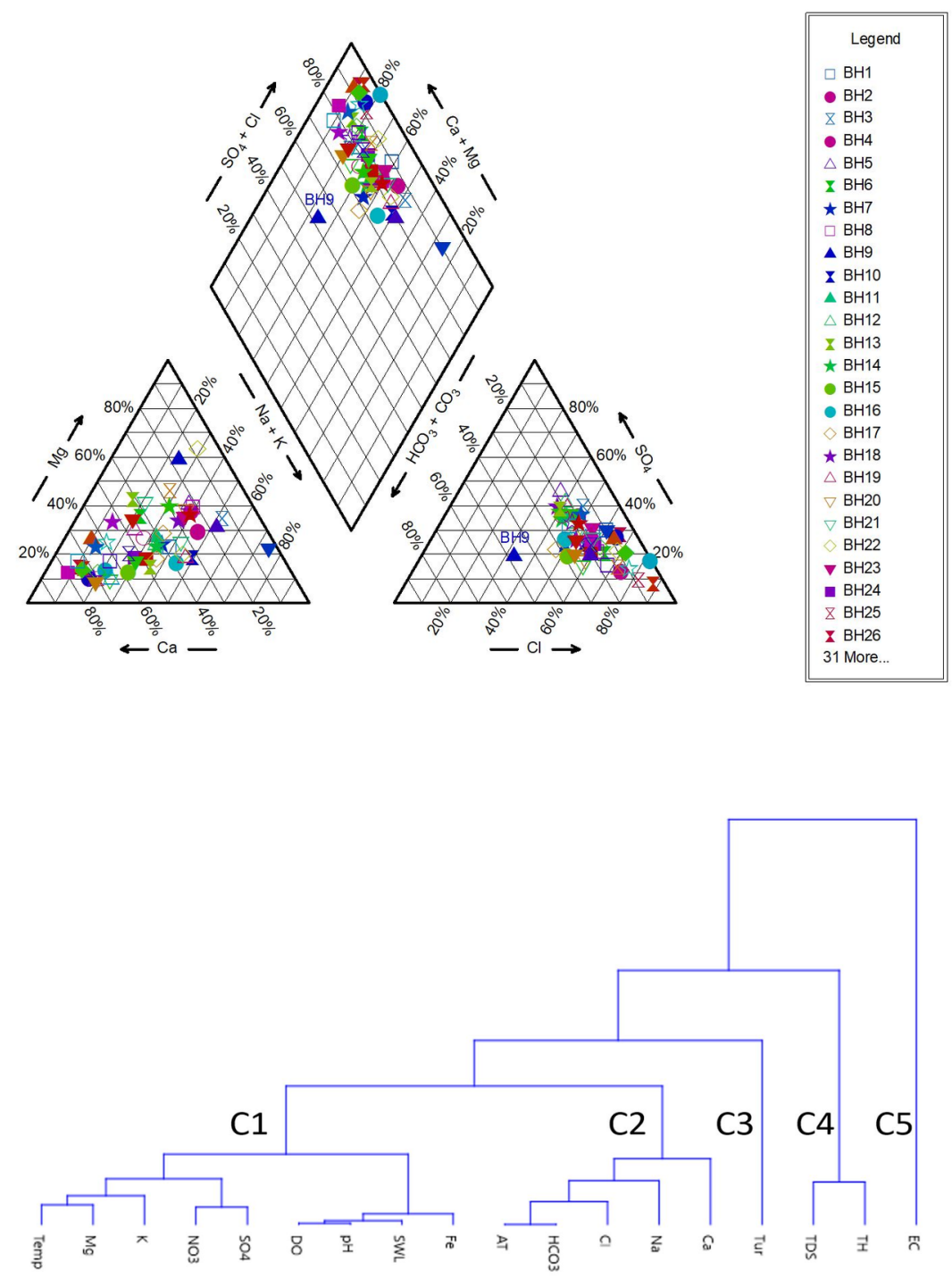

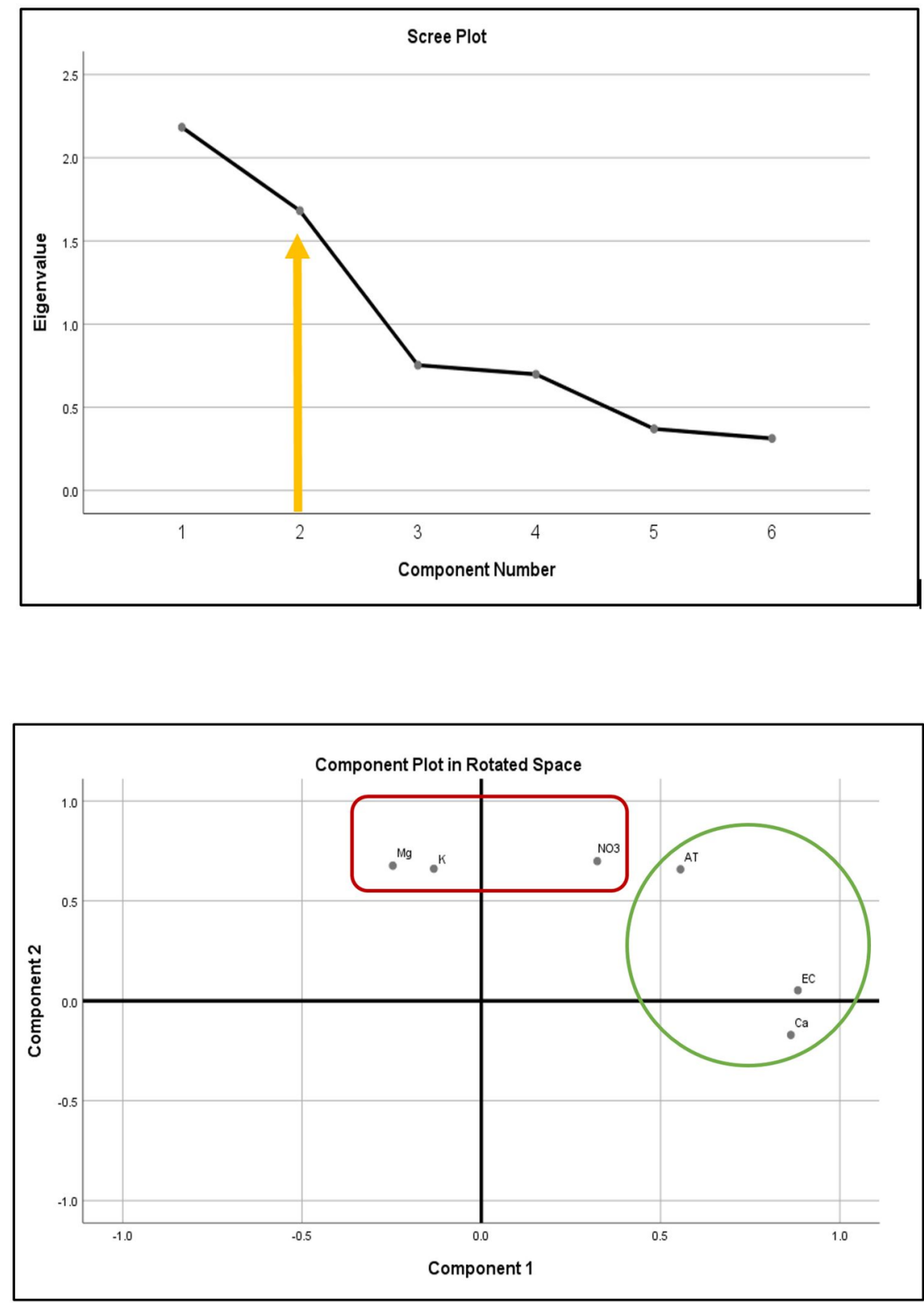

\section{Hosted file}

Table1.pdf available at https://authorea.com/users/399224/articles/511783-hydrochemicalcharacteristics-and-identification-of-groundwater-pollution-sources-in-tropical-savanna

\section{Hosted file}

Table2.pdf available at https://authorea.com/users/399224/articles/511783-hydrochemicalcharacteristics-and-identification-of-groundwater-pollution-sources-in-tropical-savanna

\section{Hosted file}

Table3.pdf available at https://authorea.com/users/399224/articles/511783-hydrochemicalcharacteristics-and-identification-of-groundwater-pollution-sources-in-tropical-savanna 


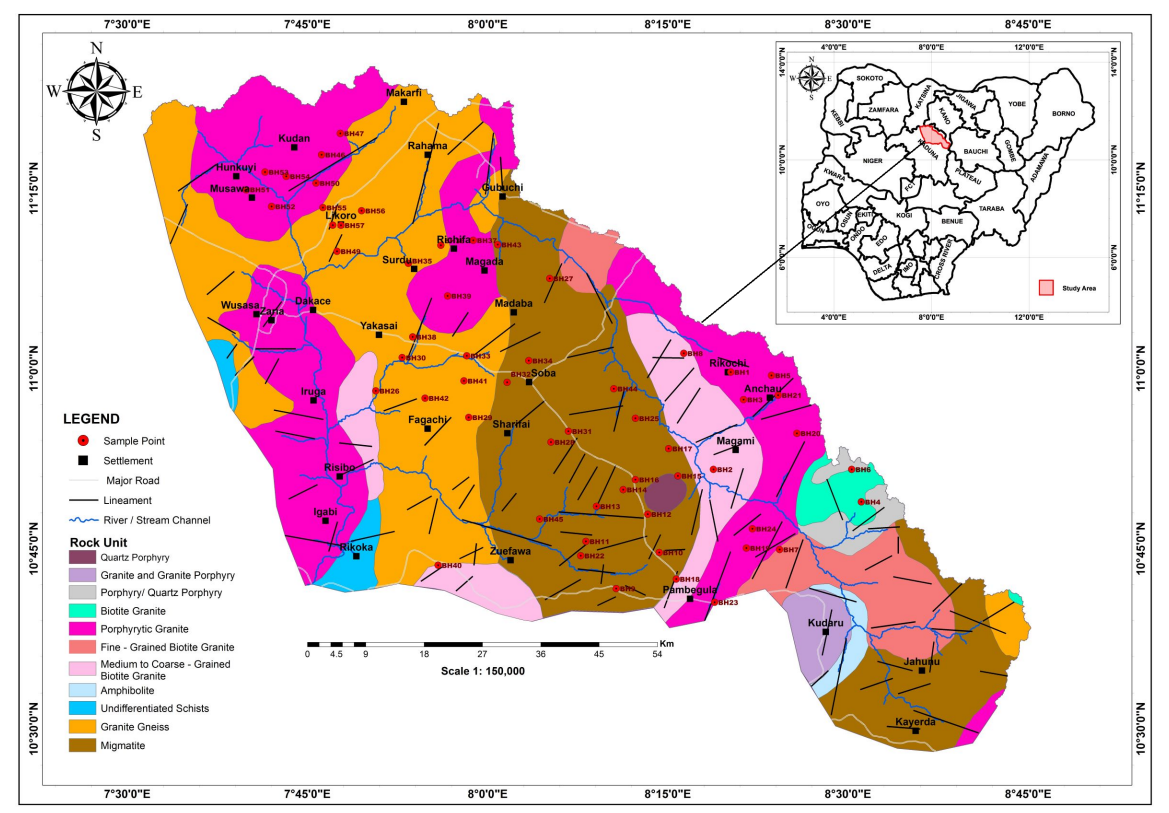

